\title{
Las pictografías del cerro Tupinachaca: memoria y control en la sierra de Yauyos*
}

\section{THE PICTOGRAPHS OF TUPINACHACA: MEMORY AND CONTROL IN THE SIERRA OF YAUYOS}

\author{
Martín Mac Kay Fulle \\ Universidad de Lima \\ Julio Rucabado Yong \\ Arqueólogo investigador y curador de arte precolombino independiente
}

\author{
Martín del Carpio Perla \\ Argia Consultores E. I. R. L. \\ Paloma Manrique Bravo \\ Arqueóloga investigadora independiente
}

\section{RESUMEN}

Este artículo explora la naturaleza y la importancia del paisaje cultural construido alrededor del cerro Tupinachaca, específicamente el conjunto de petroglifos existentes y su articulación con las actividades realizadas en el asentamiento prehispánico de Tupe, así como sus relaciones con el Tahuantinsuyo. La historia de este pueblo es prácticamente desconocida, en especial su pasado precolombino; no obstante, destaca por mantener una lengua, una vestimenta y un trabajo en metal que evoca tiempos prehispánicos.

PALABRAS CLAVE: Tupinachaca, Tupe, pictografías, paisaje cultural, vestimenta

\section{ABSTRACT}

This paper explores the nature and significance of the cultural landscape set up around the Tupinachaca mountain and its petroglyphs, that were articulated with the activities carried out in the pre-Hispanic settlement of Tupe and its relations with the Tawantinsuyo. The history of this town is practically unknown, especially its pre-Columbian past, however, it stands out for maintaining a language, traditional clothing and metal work that recall pre-Hispanic times.

KEYWORDS: Tupinachaca, Tupe, pictography, cultural landscape, clothing

\footnotetext{
*Agradecemos a Luisa Vetter Parodi por introducirnos en la increíble historia y tradiciones de Tupe. También, a Rainer Hostnig, Arturo Ruiz Estrada y Víctor Falcón por sus aportes desinteresados y por compartir con nosotros su registro gráfico.
} 


\section{INTRODUCCIÓN}

Este artículo tiene por objetivo desarrollar un estudio integral que permita comprender la importancia de las pinturas que decoran la ladera del cerro Tupinachaca, ubicado en la provincia de Yauyos, en el departamento de Lima, el cual estuvo inserto en una esfera de interacción local y regional durante el período de expansión inca. Las tumbas, estructuras ceremoniales y pictografías existentes serán comprendidas a partir de la información etnohistórica y arqueológica disponible, que será complementada con los saberes y tradiciones locales del actual pueblo de San Bartolomé de Tupe.

En una descripción de los elementos iconográficos de las pinturas se podrá diferenciar personajes y actividades representados. Asimismo, una comparación estilística con pictografías similares provenientes de diversas regiones de los Andes centrales permitirá asociar la ocupación prehispánica tardía del Tupinachaca con la presencia imperial inca. Buscaremos, finalmente, relacionar la dimensión pictórica de los diseños y escenas con su rol ceremonial.

El concepto de tinkuy, vocablo quechua que remite al "encuentro" y al espacio de encuentro de dos o más fuerzas o entidades, nos ayuda a entender mejor la naturaleza y función del Tupinachaca, pues este cerro, que contiene tumbas y diseños pintados, se ubica en las rutas de paso. Los "puntos de encuentro" son los espacios donde se permite gestar diversas transformaciones sociales de la comunidad que provoca y participa de dichos encuentros, donde se generan y resuelven conflictos, donde se negocian roles, identidades y toda relación humana. Tradicionalmente, estos espacios de encuentro han sido lugares públicos, centros monumentales de función política, religiosa y administrativa. Estas funciones, en muchas de las sociedades precolombinas del antiguo Perú, quedaron yuxtapuestas, contenidas en las acciones realizadas en los templos y plazas o en emplazamientos sagrados, y encarnadas en la figura del líder, curaca-sacerdote-chamán.

\section{SAN BARTOLOMÉ DE TUPE: ASPECTOS GENERALES}

El centro poblado de San Bartolomé de Tupe se encuentra localizado en la cuenca del valle de Cañete, distrito de Tupe, provincia de Yauyos, a 240 kilómetros al sureste de la ciudad de Lima, la capital del Perú. Se ubica a una altitud de 2840 m s. n. m., dentro de la ecozona quechua, aproximadamente a 80 kilómetros del litoral del Pacífico.

Su fundación como asentamiento colonial tuvo lugar en 1562 y estuvo a cargo de Diego Dávila Briceño, corregidor de Yauyos, encargado de extirpar las idolatrías en las etnias de Sh'ucho (Cachuy) en esta región. Este poblado fue bautizado con el nombre de San Bartolomé de Tupi. Actualmente, Tupe tiene una población aproximada de 800 habitantes y su demarcación política incluye dos poblados anexos: Aiza y Colca, que se hallan 
a una distancia aproximada de dos horas a pie del poblado central. La principal actividad de subsistencia económica es la agricultura, la cual es complementada con la ganadería.

El poblado central de Tupe se encuentra al lado de una quebrada profunda, en la unión de dos ríos: el Chancay, cuyas aguas corren hacia el lado sur del poblado; y el Uchapaya, al norte del mismo. Ambos ríos confluyen cerca de la entrada del pueblo creando de esta forma el río Tupe. Asimismo, este asentamiento se emplaza al lado del cerro Tupinachaca, macizo de piedra considerado localmente como el apu tutelar o ancestro de la comunidad, función simbólica que parece tener su origen en tiempos precolombinos.

La lengua nativa local es el jaqaru, que está emparentada lingüísticamente con el aimara de la región surandina. Si bien el castellano es la lengua oficial, la educación escolar es bilingüe y los tupinos adultos se comunican en jaqaru. Esta lengua pertenece a la familia aru, de la que derivan el cauqui-aimara o jaqui y el cauqui o jaqaru. La palabra jaqaru se deriva de jaqui que significa "gente" y aru que significa "hablar". Para Martha Hardman, existen dos lenguas diferentes en el distrito de Tupe: el cauqui de Cachuy y el jaqaru o cauqui tupino de Tupe. No obstante, para Torero (2002), se trataría de una sola lengua con muchos usos locales, una larga historia de interferencias entre idiomas arus y quechuas, agravada por el trueque y variaciones fonológicas que van quedando en desuso ante el avance del castellano.

El desarrollo y evolución del protoaru se inició, según Torero $(2000,2002)$, con el proceso de neolitización del territorio andino, que propició la diferencia lingüística por el aislamiento derivado de la accidentada geografía. Luego de 3000 años de este proceso de adaptación, se iniciaron los contactos entre los distintos grupos. Esta aproximación favoreció la difusión de algunas lenguas a nivel regional, como el protoquechua y el protoaru, cuyos lugares de origen estuvieron en el centro y el sur de la costa peruana, respectivamente. Para el Horizonte Medio (600 a 1000 d. C.), el aru tenía tres ramas: Yauyos, Chocorbos y Lucanas. El primero incluía el jaqaru. Ya en el Intermedio Tardío (1100 a 1400 d. C.), los yauyos (aru) avanzaron hacia el norte, conquistaron la provincia de Huarochirí y quizá la de Canta, y permanecen ahí hasta la actualidad.

Otro elemento importante de la identidad tupina se manifiesta a través de las vestimentas tradicionales. En el poblado central de Tupe destaca el uso del anako y de los tupus entre las ancianas, ambas prendas de origen precolombino. En la vestimenta tradicional de las mujeres se distingue el traje típico y el cotidiano.

La vestimenta típica (figura 1) está conformada por el cotón o camisón negro, sobre el cual visten un delantal negro con ribetes rojos, elaborado con lana de alpaca, llamado anako. En la espalda, se lleva una manta de color negro con franjas en tonos rojizos, que se asegura de forma cruzada sobre el pecho utilizando tupus. Encima del anako va la faja interna o marate, hecha de lana y champacara (hoja de maguey), la cual sujeta la faja de lana de vicuña de color marrón o rojo. A la altura de la cadera, debajo de la faja, 
se coloca la huaraca o cintas de lana con pompones. Completan la vestimenta un tocado compuesto por un pañuelo rojo o negro que se usa en la cabeza, amarrado de diferentes formas; borlas dispuestas en las trenzas; y aretes denominados tres caídas, hechos con monedas de plata. Sobre el pecho cuelga, desde el cuello, el piñe o adorno de antiguas monedas también de plata, cuyas fechas de emisión van desde 1850 hasta 1980.

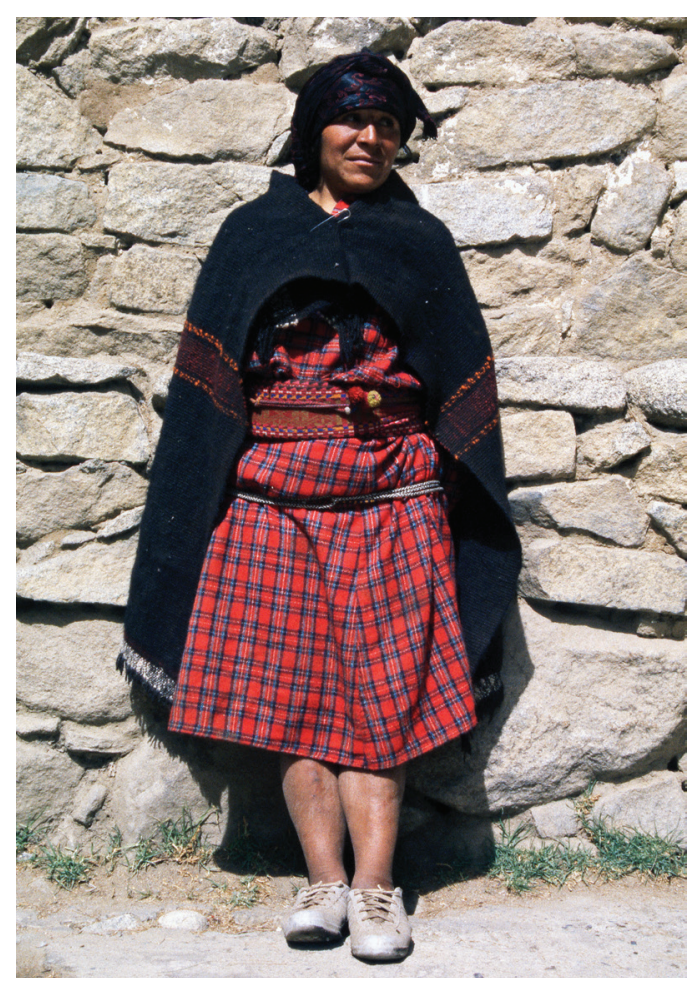

Figura 1. Vestimenta típica*

La vestimenta cotidiana (figura 2) consiste en un camisón a cuadros confeccionado con telas de algodón o franela de distintas tonalidades de rojo, Llevadas desde Lima. La manta es la misma que la usada en la vestimenta típica y se coloca de manera similar, asegurada con un prendedor en vez de tupu. Los otros complementos, como el tocado, el marate, la faja, la huaraca y el calzado o shucuy, son iguales a los descritos en la vestimenta típica. Sin embargo, en lugar de usar el piñe o los aretes tres caídas, llevan llaves colgantes pequeñas. El pañuelo en la cabeza cumple una función utilitaria, sobre el cual se ciñe a la frente una cuerda que cae por la espalda y soporta un peso de hasta 100 kilos.

* Todas las fotos de ese artículo son de Luisa Vetter y Martín Mac Kay. 


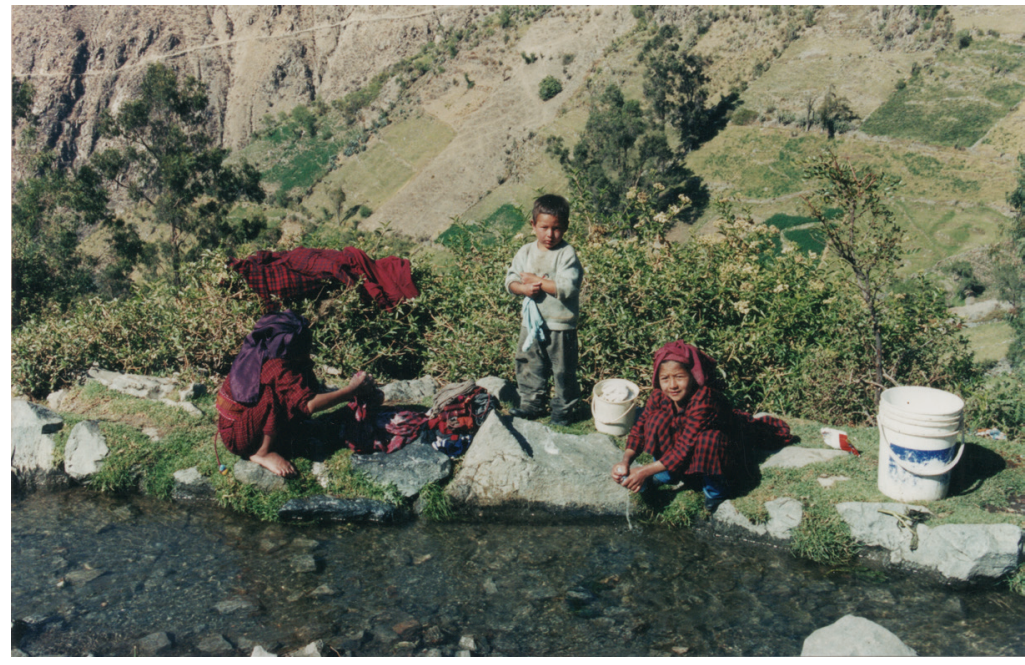

Figura 2. Vestimenta cotidiana

En el caso de los varones de Tupe, destaca el uso de prendas fabricadas con telas de diseño escocés, introducidas a mediados del siglo xx.

Los tupus son uno de los componentes principales de la vestimenta típica de las mujeres tupinas de mayor edad. Estos prendedores, aunque han sido asociados con los incas, han sido utilizados en la vestimenta femenina prehispánica desde el año $400 \mathrm{~d}$. C., como lo muestran los ceramios mochicas y nascas. Durante la Colonia, la iconografía de los tupus se complejiza, pues se observan personajes y escenas. Se elaboran solo en plata, a diferencia de la época prehispánica, en la que se confeccionaban en cobre, bronce, plata u oro. A partir de la República, la forma de usar el tupu varía: la aguja ya no se coloca en forma diagonal, sino horizontal, como los prendedores españoles.

Los tupus de las mujeres de Tupe se asemejan a los coloniales; tienen forma circular y presentan una iconografía que simboliza el sincretismo entre lo andino y el Viejo Mundo. Vetter y Mac Kay (2008), durante su visita a Tupe, observaron dos pares de tupus con decoración repujada de un águila bicéfala (figuras 3 y 4), que recuerdan el escudo familiar de los Habsburgo de la época de Carlos I de España, quien reinaba al momento de la conquista del Perú. Para los autores, el águila bicéfala se relaciona con la representación del símbolo del poder político en el mundo andino. Otro motivo observado en los tupus es el escudo nacional, cuyo diseño se remonta a mediados del siglo xix. Este diseño y el del águila bicéfala trazados en los tupus serían la representación del poder central en la época de la Colonia y posteriormente durante la República. En tal sentido, 


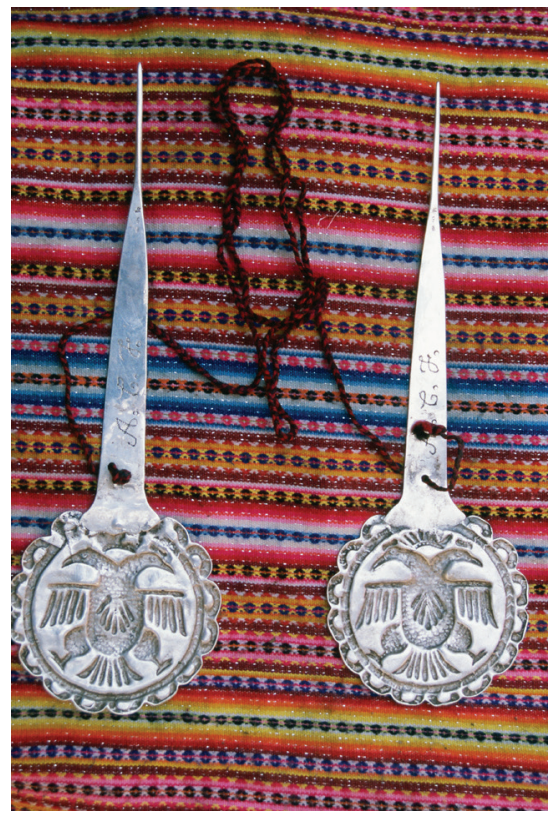

Figura 3. Tupus con diseño de águila bicéfala

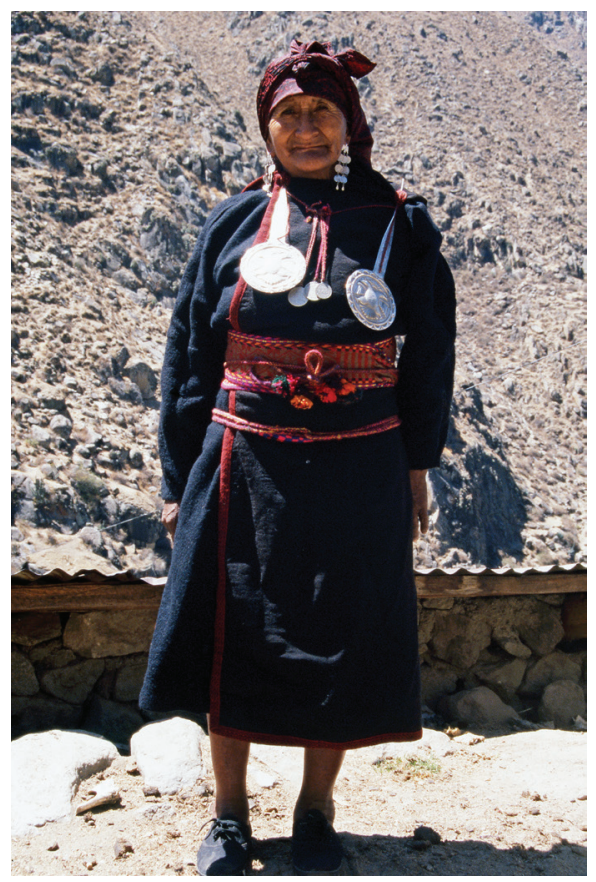

Figura 4. Uso de tupus en la vestimenta 
es válido preguntarse qué estuvo representado antes de la llegada de los españoles.

Los diseños representados también serían un indicador de la importancia política de la persona que los usa, o los identifica como miembros de un grupo de poder o pertenecientes a un grupo étnico de prestigio, como, por ejemplo, ser descendiente de los curacas yauyos.

\section{TUPINACHACA, EL TUPE PREHISPÁNICO}

\section{Estudios etnohistóricos y arqueológicos}

Las investigaciones sobre Tupe han girado principalmente en torno a la información extraída de fuentes escritas durante la conquista y los primeros años de la Colonia, entre los siglos XVI y XVII. Las dificultades del trabajo de campo en sitios de altura y la falta de arquitectura monumental han sido factores disuasivos para la investigación arqueológica en esta localidad.

Destacan los estudios de Pedro Villar Córdova (1935) y María Rostworowski (2002, p. 206), basados en documentos sobre Diego Dávila Briceño, primer corregidor de Yauyos, territorio que fue el área nuclear del pueblo yauyo y al cual perteneció la población que habitaba el antiguo Tupe. El territorio yauyo habría abarcado, entre los siglos XI y XV, antes de la llegada de los incas a la región, las cabeceras de los valles de Lurín, Rímac (Huarochirí) y Chillón (Canta). Esta posición intermedia convirtió al pueblo yauyo en una suerte de intermediario en el contacto entre las sociedades del litoral y las que habitaban en la puna. De esta manera, los yauyos difundieron su cultura en las serranías del actual departamento de Lima, dejando como testimonio dos elementos importantes: por un lado, su lengua, el cauqui o jaqaru —también llamado a'karo, según Julio C. Tello (1929)— $y$, por el otro, su arquitectura caracterizada por estructuras denominadas mastabas por el padre Villar Córdova (1935, p. 357). Estas se encontraban ubicadas en tres sitios: Tupinachaca, Mallma y Umay. Actualmente, sabemos que estas mastabas fueron cistas funerarias hechas de piedra canteada sin labrar y con uso ocasional de mortero de barro.

Julio C. Tello realizó excavaciones en la zona. Lamentablemente, estos trabajos nunca fueron publicados y los materiales recuperados se perdieron en los depósitos de distintos museos. Sin embargo, sabemos por las notas del sabio peruano (Matos Mar, 1956, p. 8) que entre los materiales hallados se encontraban ceramios, instrumentos de plata, cobre y bronce (entre ellos, tupus) y gran cantidad de textiles. Casi todo este material fue asociado por Tello a culturas costeñas vecinas de los valles de Cañete, Pisco y Chincha, pero sobre todo al estilo de Tiahuanaco (Matos Mar, 1956). Recordemos que, en aquellos años, Tiahuanaco o tiahuanacoide era la denominación de lo que hoy son los 
distintos estilos cerámicos del Horizonte Medio (600 a 1000 d. C.).

El sitio arqueológico de Tupinachaca se ubica a más de un kilómetro al noroeste del actual poblado de Tupe, en la parte media del cerro que le da nombre. Este cerro es reverenciado por la población actual como apu protector. Hasta el día de hoy, los pobladores se refieren a él como el anciano defensor, lo que es fácil de entender, pues es una de las grandes cumbres que rodean el pueblo, con una cima que llega hasta los 3840 m s. n. m., y que, además, desliza las aguas del río Chancay hacia el poblado. En la parte media del cerro, se distinguen los tres sectores que, junto con el cerro, componen y le dan significado al paisaje cultural de Tupinachaca.

A continuación, presentamos las características de cada sector a partir de las descripciones de Pedro Villar Córdova (1935) y de nuestra visita al sitio.

\section{Cistas funerarias (sector I)}

El primer sector es un conjunto de cistas funerarias ubicadas en pequeños abrigos rocosos o cavernas naturales de no más de cuatro o cinco metros de profundidad, en la cara sur del cerro Tupinachaca, con sus entradas orientadas hacia el río Uchapaya. Su arquitectura es de piedra canteada sin labrar, colocada prácticamente sin mortero y formando una planta cuadrangular que ocupa toda la superficie del abrigo rocoso.

Estas cistas tienen una altura no mayor de 1,50 metros; sin embargo, gran parte de las estructuras se encuentran bajo tierra, por lo que consideramos a esta forma de enterramiento como semisubterránea. El tipo de construcción funeraria ha impedido que algunas tumbas hayan sido saqueadas. A pesar de sus dimensiones pequeñas, las cistas de Tupinachaca son comparables con todas las estructuras funerarias ubicadas en las cabeceras de los valles del Chillón y Rímac (por ejemplo, las de los sitios de Cantamarca, Chipprak, San Pedro de Casta, San Juan de Iris, entre otros).

Según datos de Villar Córdova (1935), de los propios pobladores de Tupe y de nuestras observaciones realizadas en el sitio, los cuerpos fueron colocados dentro de las cistas en posición sentado-flexionada y su estado de conservación es muy bueno. De acuerdo con los restos óseos estudiados, estas cistas podrían haberse utilizado durante un lapso prolongado de tiempo, ya que se depositó una gran cantidad de individuos en cada una de ellas. Los cuerpos corresponden a ambos sexos y un amplio rango de edad.

Es sumamente importante mencionar que estos contextos funerarios se encuentran asociados a una gran cantidad de terrazas que muy probablemente habrían servido como base de las viviendas de los antiguos pobladores del lugar. Las terrazas son adyacentes a zonas de cultivo con andenería, que son irrigadas por los ríos Uchapaya y Chancay. Actualmente, en ellas se producen cultivos que abastecen a los pobladores de Tupe. En toda el área se observa, además, gran cantidad de fragmentos de cerámica utilitaria, 
mayormente ollas con hollín y cántaros. Existen también evidencias de instrumentos líticos como morteros, manos de moler y pequeños instrumentos hechos de cantos rodados.

La conformación del sitio hace que no exista separación espacial entre los muertos y los vivos. La "vecindad" entre tumbas y hogares parece ilustrar la necesidad de mantener o extender los vínculos físicos y sociales con los muertos y los ancestros, integrándolos a la vida comunitaria. El rol de los ancestros como vigilantes de la comunidad (y de sus actividades productivas o de subsistencia) podría también verse reflejado en este cercano emplazamiento del área funeraria.

A estas evidencias se suma la integración entre el apu Tupinachaca y los ancestros, lo cual queda sugerido por el acto simbólico de introducir los cuerpos en las cistas al interior de los abrigos rocosos de las laderas del cerro. Esto les permite ingresar y encontrarse con la propia deidad tutelar del pueblo.

\section{Altar lítico (sector II)}

El altar lítico es una gran piedra, conocida por los pobladores como "piedra de tacitas", ubicada en las cercanías de las estructuras funerarias antes descritas, a 100 metros al este del farallón de las pictografías, prácticamente en las orillas del acantilado que da forma a la ladera sur del Tupinachaca. Tello (1929, p. 37) fue el primero en mencionar esta "roca excavada", que se trata de una gran laja plana que mide $3 \times 2$ metros, aproximadamente. Tiene labradas cinco depresiones circulares de poca profundidad, que forman una línea casi recta. Cada una de estas concavidades tiene un promedio de 50

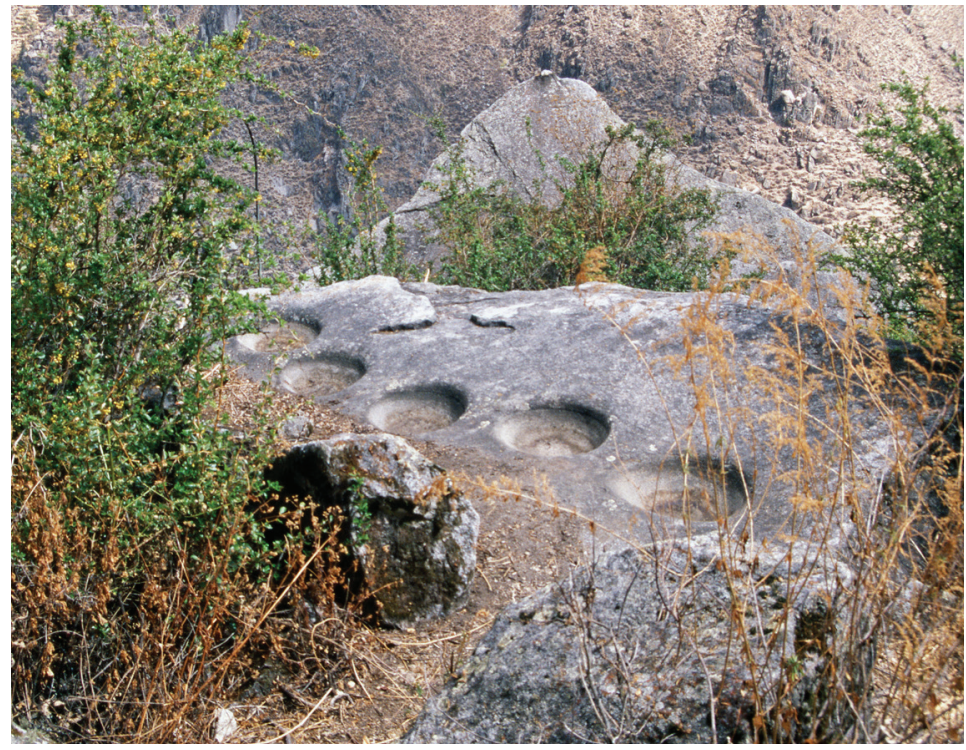

Figura 5. Altar lítico conocido como "piedra de tacitas" 
centímetros de diámetro y están separadas entre sí por una distancia menor a 10 centímetros (figura 5).

Este tipo de piedras con depresiones circulares no son raras en la arqueología andina; están presentes desde el período Formativo (3000 a 100 a. C.) hasta la época inca. Sitios tempranos como Chavín de Huántar (altar de Choque Chinchay o de las siete cabrillas) en la actual provincia de Huari, departamento de Áncash, y Poro Poro (altar de La Grada), en la provincia de Santa Cruz, departamento de Cajamarca, presentan este tipo de cavidades que han sido asociadas generalmente a rituales vinculados con las lluvias y la fertilidad, o a la observación astronómica mediante su uso como espejos de agua, los cuales reflejarían posiciones de estrellas en un tiempo determinado, quizá durante el inicio o el fin de las lluvias (Del Carpio, Mac Kay y Santa Cruz, 2001, pp. 110-111).

En el caso de la piedra de Tupinachaca, nos arriesgaríamos a afirmar, a partir de las características de los sitios ya mencionados y de la presencia de cerámica negra aparentemente formativa (chavinoide) vista por Tello (1929, p. 98) en la década de 1920, que esta piedra o altar lítico correspondería a una ocupación anterior al tiempo de los yauyos, quizá una evidencia del período Formativo, muy probablemente de las fases media a tardía (1000 a 600 a. C.).

\section{Las pictografías (sector III)}

El tercer sector está compuesto por un conjunto de pinturas rupestres o pictografías ubicadas sobre un farallón natural de la misma ladera sur del Tupinachaca donde se encuentran las estructuras funerarias. Las pinturas se pueden observar desde el pueblo actual, debido a su excelente ubicación y a la conformación natural del farallón rocoso, el cual es prácticamente vertical y tiene cerca de 15 metros de altura. Estas imágenes han sido pintadas casi en su totalidad con algún instrumento de tipo brocha o con las manos. El color de los diseños es ocre rojo (solamente una pintura está acompañada de un pigmento blanco) obtenido de algún elemento con óxido de hierro. Los escasos pigmentos blancos quizá hayan sido elaborados con arcilla líquida. Morteros y manos de moler, que posiblemente formaron parte del proceso de producción de las pinturas, se han registrado cerca de las cistas y en el camino que rodea al Tupinachaca, durante 


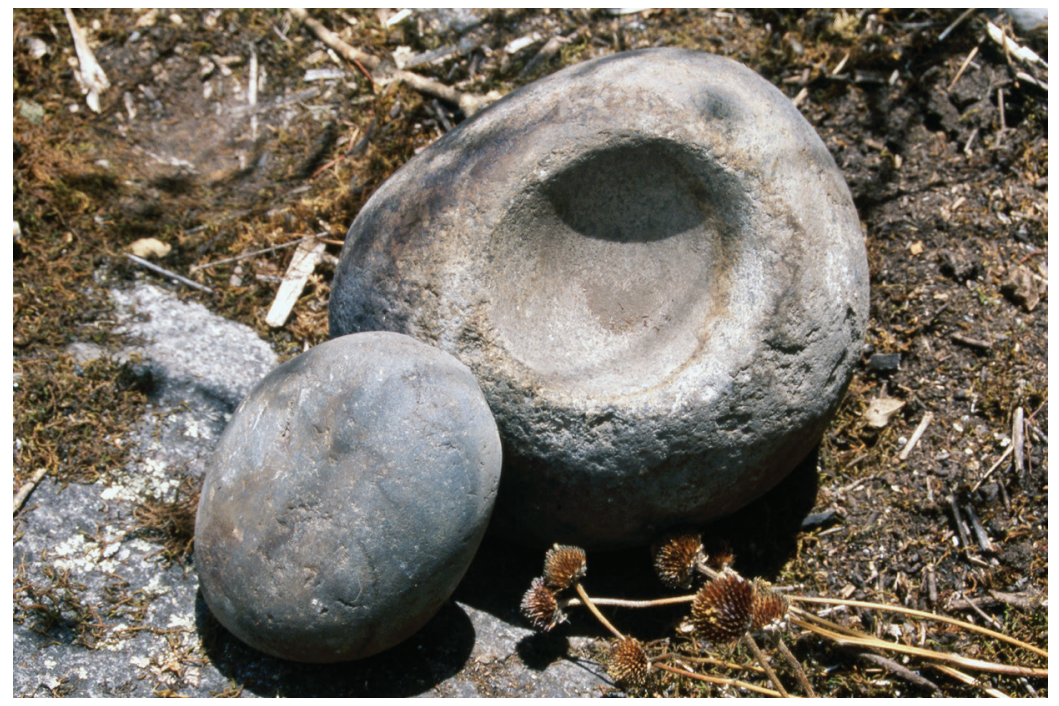

Figura 6. Mortero y mano de moler

nuestra visita a la zona (figura 6).

Las pictografías se encuentran a una altura que supera los 2 metros, lo cual nos llevó a pensar en la construcción previa de andamios para pintar los diseños, utilizando grandes piedras existentes en la base del farallón que, por su disposición, habrían servido como escalones y que, en algunos casos, llegan a la altura donde se ubican los diseños. Además, todos estos dibujos están rodeados de bases de estructuras de piedra canteada muy sencillas; estas conformaron plataformas que pudieron tener una función de pequeño escenario para actividades especiales o, en todo caso, sirvieron como sostén de estructuras perecibles.

Las pinturas se encuentran aglutinadas en un gran panel donde reconocimos diversos conjuntos de diseños. De izquierda a derecha, observamos los siguientes elementos y conjuntos:

1. Personajes antropomorfos frontales de brazos extendidos, asexuados y con tocado de tipo media luna. Son llamados "hombres arcoíris" por los pobladores (figura 7). Existen dos de estos personajes, cada uno ubicado en los extremos laterales del panel. 


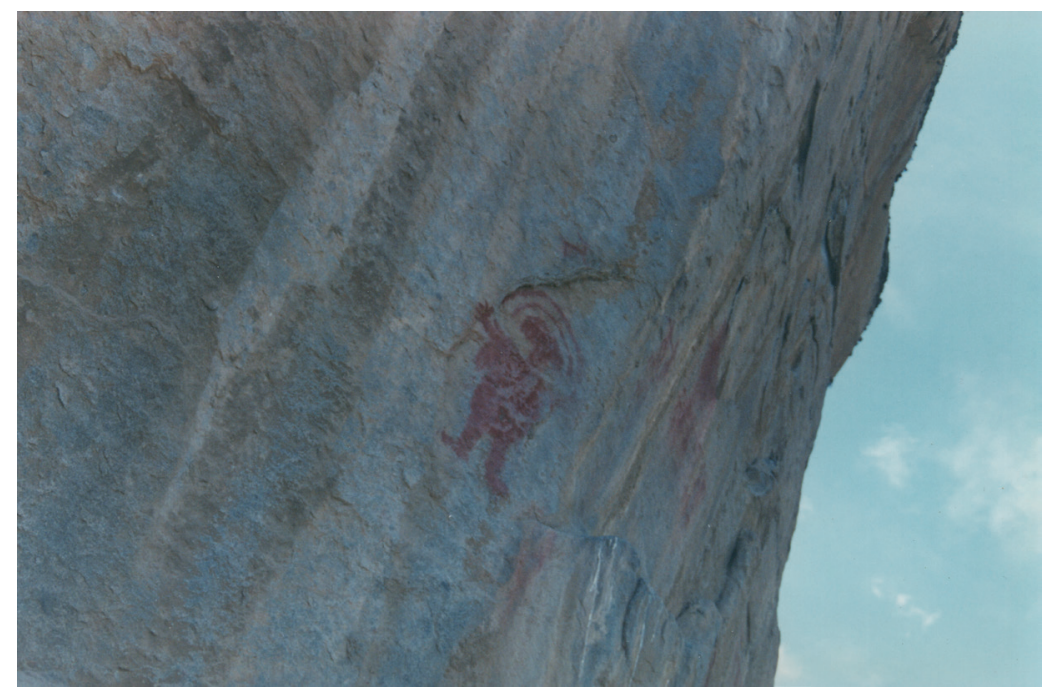

Figura 7. Personaje antropomorfo conocido como "hombre arcoíris"

2. Personajes antropomorfos frontales que tienen a sus pies otros personajes similares de menor tamaño, con brazos extendidos y genitales masculinos. Estos personajes menores están acompañados de figuras zoomorfas: probables camélidos de perfil (figura 8).

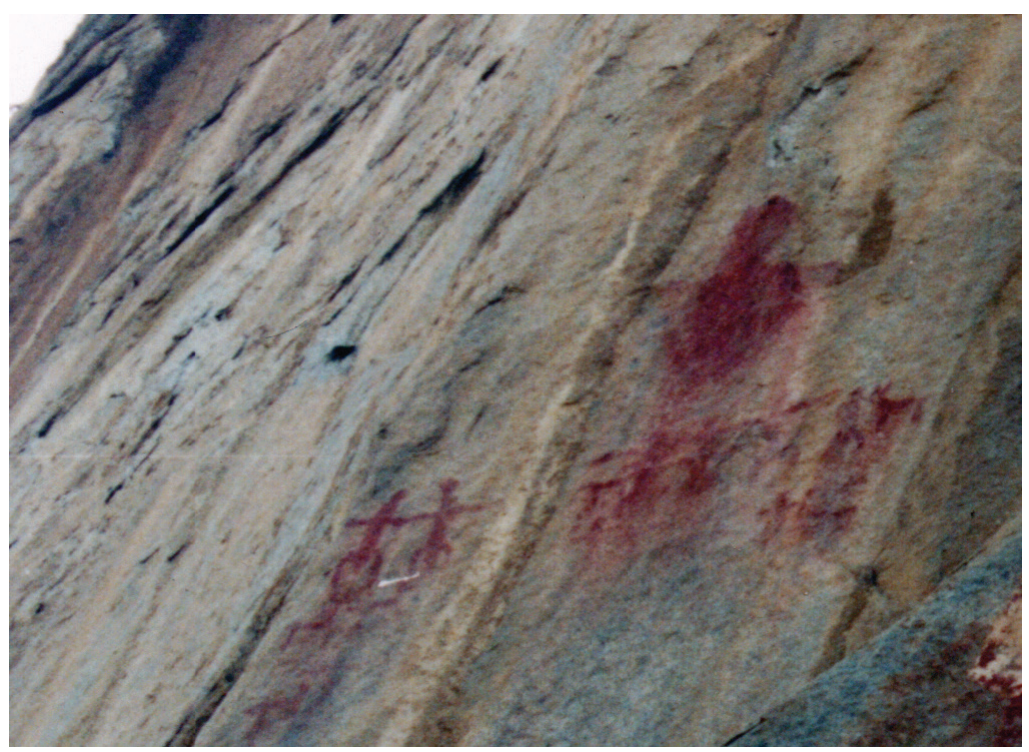

Figura 8. Personaje antropomorfo con brazos extendidos 
3. Personaje antropomorfo frontal de brazos extendidos, asexuado y con tocado de tipo "arcoíris". Lleva un unku bicolor o camiseta cuadrangular sin mangas, con cuello generalmente en $\mathrm{V}$ (figura 9).

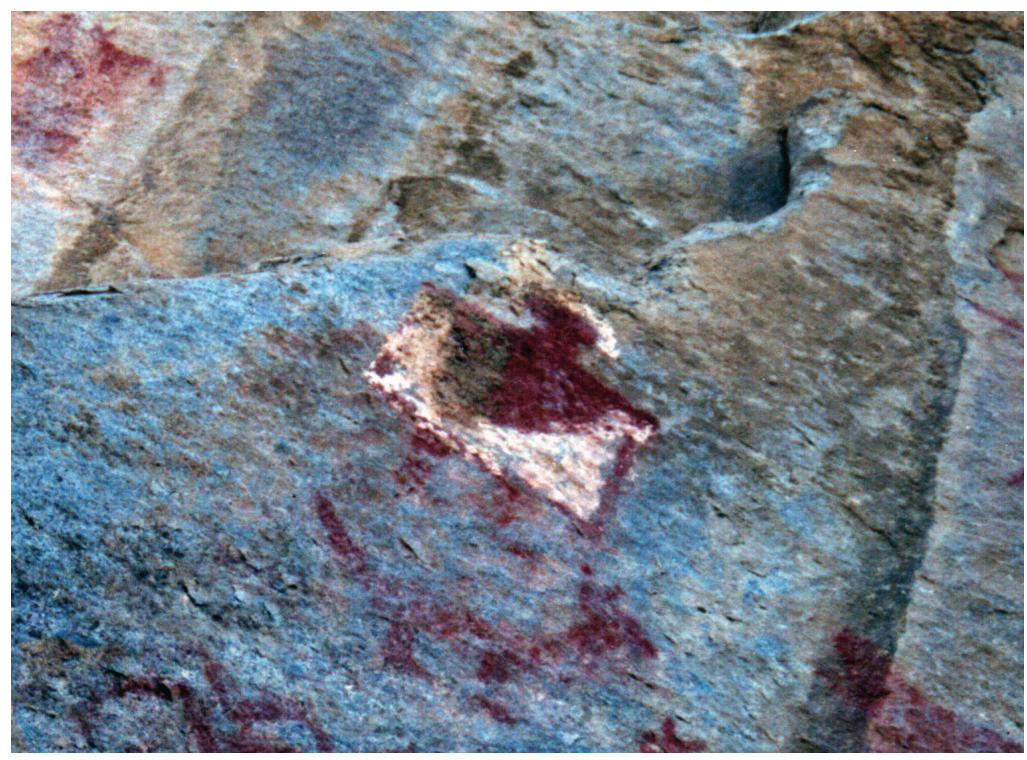

Figura 9. Personaje antropomorfo usando chuko y unku

4. En el segmento inferior del panel, se observan diseños zoomorfos cuadrúpedos, posibles camélidos, dirigiéndose tanto al oeste como al este. También se reconoce un diseño ondulante que los lugareños llaman "la serpiente", aunque es posible que se trate de un símbolo que señale movimiento de líquido. Otro diseño conocido localmente como "el bote" se asemeja a una forma de cuchillo ceremonial o tumi'. En la parte superior de esta escena, se puede ver un diseño con forma de ave con las alas desplegadas. Debajo de esta figura se reconoce un diseño simple compuesto por franjas (figura 10).

1 El tumi o cuchillo ceremonial de los Andes se caracteriza por la hoja de metal en forma de media luna. Fue usado con fines rituales. 


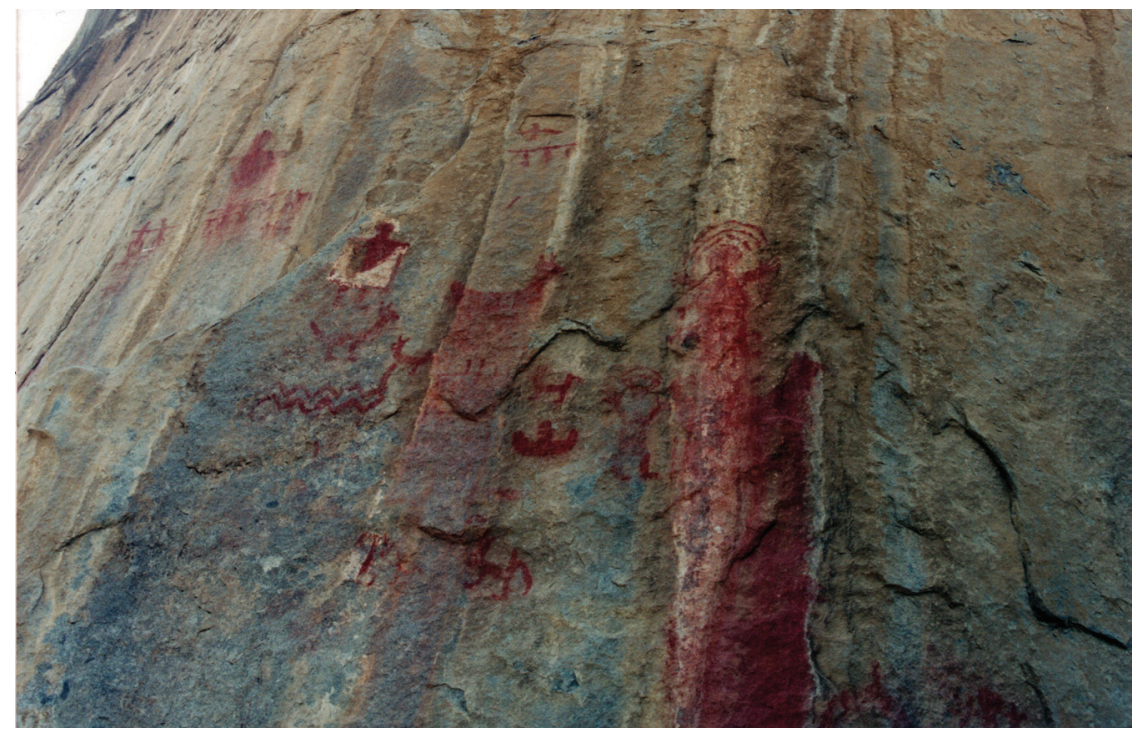

Figura 10. Vista de camélidos, tumis y líneas onduladas, que posiblemente representan flujos de agua

5. Personaje antropomorfo frontal, asexuado, con tocado de "plumas" o "pelos erizados". Está acompañado de dos grandes camélidos (que al parecer están en movimiento, a diferencia de otros diseños similares) y un círculo a su lado derecho.

6. Al menos cuatro personajes antropomorfos pequeños, muy similares a los descritos en el párrafo anterior, aunque muy borrosos. Uno de ellos sujeta un probable camélido. Esta escena se encuentra en una pared, a la derecha del resto de escenas, en una zona baja, a tan solo 1,50 metros de la superficie.

A partir de la descripción anterior se puede plantear una clasificación de los diseños en tres grandes categorías: antropomorfos, zoomorfos y diseños varios.

Diseños antropomorfos:

a. Grandes, con tocados de media luna, brazos extendidos y asexuados

b. Pequeños, con brazos extendidos y miembros masculinos

Diseños zoomorfos:
a. Camélidos pequeños en posición estática
b. Camélidos grandes en actitud de carrera
c. Ave con alas extendidas 
Diseños varios:
a. Líquido en movimiento o "serpiente"
b. Cuchillo, tumi o "bote"
c. Diseños sin definir

Asimismo, se pueden determinar dos momentos en las pinturas. El primero está conformado por los conjuntos $2,4,5$ y 6, cuyos trazos son más simples y esquemáticos, donde se observan personajes antropomorfos pastoreando camélidos. Entre estos diseños se encuentran representaciones de cuchillos o tumis y líquido en movimiento, que podría estar asociado a actividades rituales de sacrificio de camélidos. Los tupinos cuentan que en la antigüedad se hacían sacrificios de llamas en el Tupinachaca y, hasta el día de hoy, llegan a Tupe pastores de la puna para hacer intercambio de productos.

Las llamas, alpacas y vicuñas son animales que desde tiempos prehispánicos son parte fundamental de la economía y subsistencia de los pobladores de las cabeceras de los valles de la costa central. Según algunos de los pobladores entrevistados, a tres horas al este de Tupe, en la zona denominada Porochik, camino hacia el departamento de Huancayo, ya es posible encontrar llamas, alpacas y probablemente guanacos. Por su parte, Matos Mar (1951, pp. 4-5) hace referencia a la ganadería de camélidos en la puna cercana a Tupe, y menciona que, además de las especies "puras", existen diversos cruces como las crías de alpacas y vicuñas, y el mishte o cruce de llamas y alpacas. Lamentablemente, desde la introducción española de ovinos, caprinos y vacunos, la crianza de camélidos ha disminuido dramáticamente.

Hay que recordar que las nacientes de los valles eran la principal puerta de acceso de las caravanas procedentes de la puna y de la misma hoya del Mantaro, las cuales se trasladaban hasta el litoral en busca de productos de intercambio. Este movimiento comercial fue una de las actividades más beneficiosas del señorío de los yauyos, quienes sirvieron de nexo entre ambos extremos de la red comercial puna-costa, como mencionamos párrafos atrás.

Asimismo, los camélidos son un importante elemento de los rituales propiciatorios de nuestras serranías desde épocas inmemoriales. Los sacrificios de llamas han sido registrados desde las primeras crónicas. En Tupinachaca, eran ofrecidos para solicitar buenas siembras, incluso en el siglo xx (Delgado de Thays, 1959, p. 274). Polia (1999, p. 114) señala que los camélidos se ofrecían como "sacrificios mayores" y, según algunos cronistas, se preferían los albinos. Añade que Cristóbal de Molina los llamó barcapaña, los cuales eran ofrecidos al Sol, mientras que Santa Cruz Pachacuti Yamqui los denominó arpay. Otro detalle importante registrado por Polia (1999, p. 115) es el uso del sebo de llamas o wira para ciertas actividades rituales. 
El segundo momento identificado en las pinturas rupestres corresponde a los elementos 1 y 3 , descritos líneas arriba. Se trata de tres personajes que llevan un tocado de media luna, pero uno usa, además, un unku de color rojo y blanco. Este se ubica en el centro del panel y los otros dos en cada extremo. Estos tocados son muy similares a los cascos de madera que utilizaban los militares incas en la guerra y que en las crónicas se denominan chukos, los cuales aparecen representados en los dibujos y acuarelas de Guamán Poma (1993) hacia 1615 y de Martín de Murúa (1962) hacia 1617. Por la vestimenta, los adornos y el casco de las pinturas, es posible indicar la filiación tardía de este segundo momento.

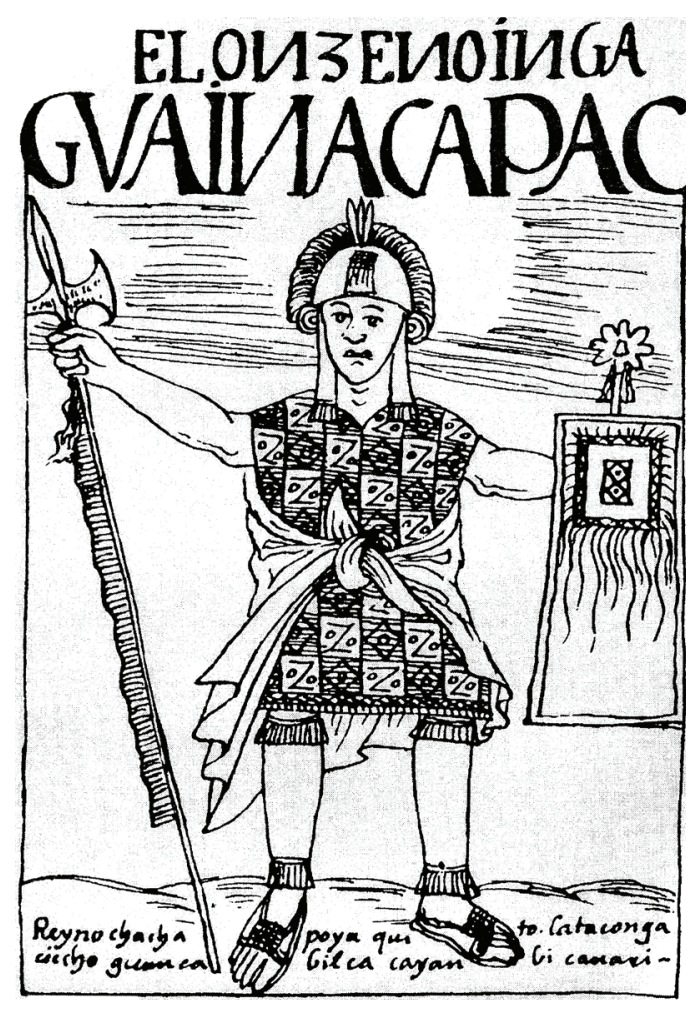

Figura 11. Militar inca usando chuko y unku, representado por Guamán Poma (1993) hacia 1615

En comparaciones estilísticas con estudios y observaciones presentados por otros investigadores sobre pictografías tardías de la época inca, se reconocen diseños similares a los de Tupinachaca. Rainer Hostnig (2017) registró representaciones de personajes vistiendo chukos y unkus en los sitios incas de Nawpakachi en Maras (figura 12), Banderayoq y K'echuqaqa en Urubamba (figura 13), departamento de Cusco. 


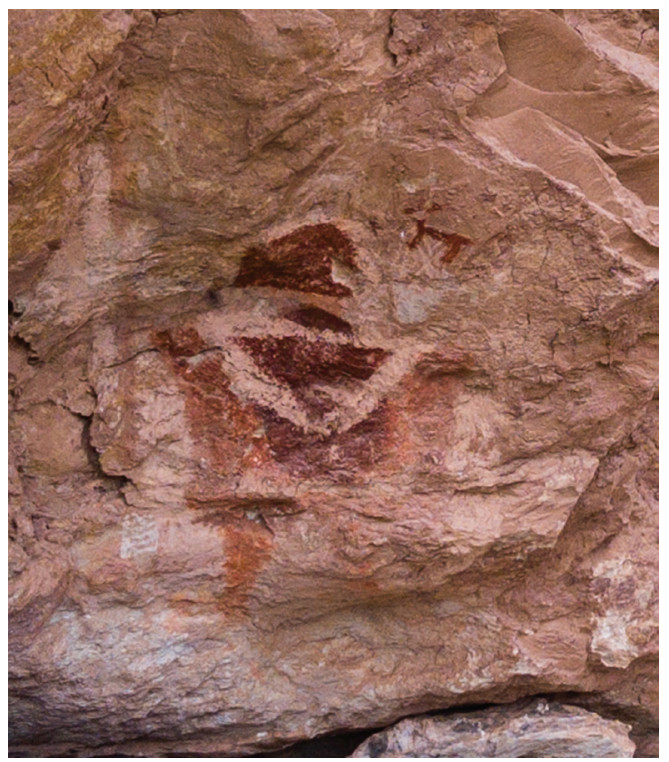

Figura 12. Pictografía que representa a un personaje usando unku y chuko en el sitio arqueológico inca Nawpakachi (cortesía de Rainer Hostnig)

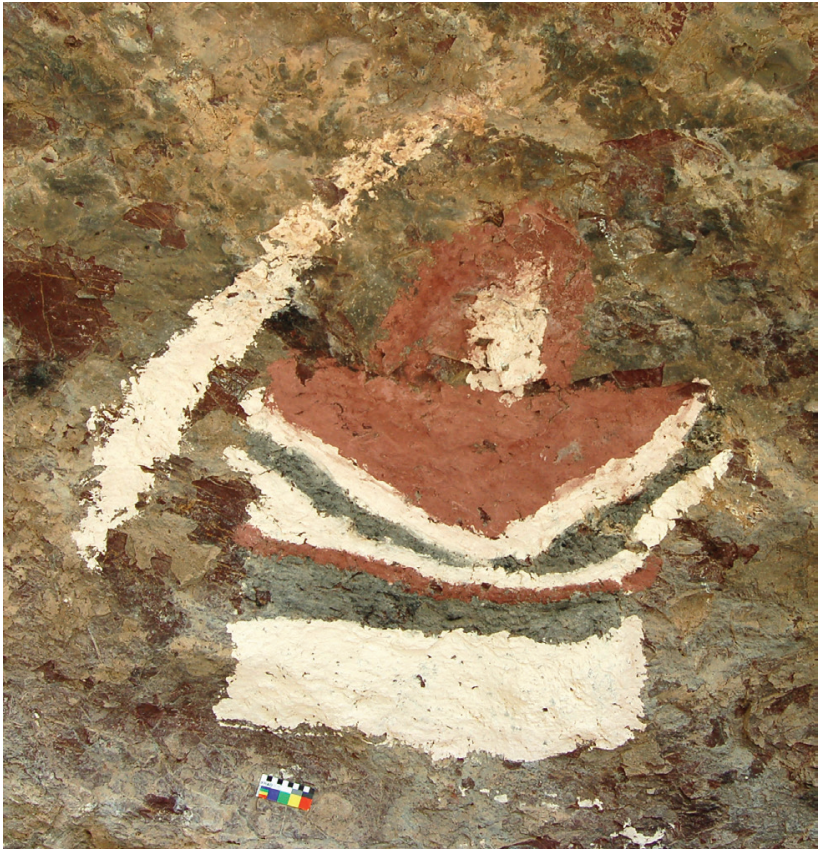

Figura 13. Pictografía que representa a un personaje usando unku y chuko en el sitio arqueológico inca K'echuqaqa (cortesía de Rainer Hostnig) 
Víctor Falcón (2015) halló en el sitio de Inkapintay, ubicado en Ollantaytambo, un personaje completo que podría ser la representación de Manco Inca (figura 14). El diseño y los colores del unku que viste este personaje son iguales a los de Tupinachaca.

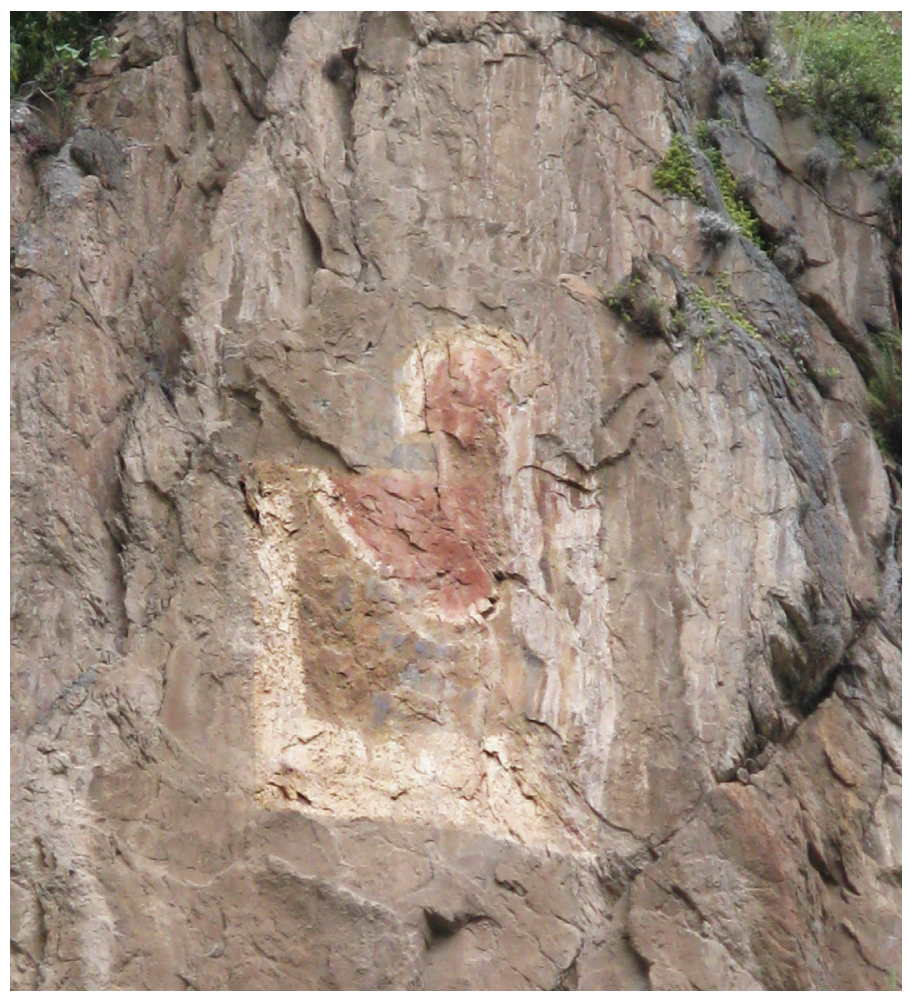

Figura 14. Pictografía de personaje con unku y chuko en el sitio arqueológico Inkapintay (cortesía de Víctor Falcón)

Arturo Ruiz (2007) encontró en el sitio Chanque, ubicado en Luya, Amazonas, pinturas de diferentes unkus con diseños incas, tumis y personajes estilizados (figuras 15, 16 y 17). 


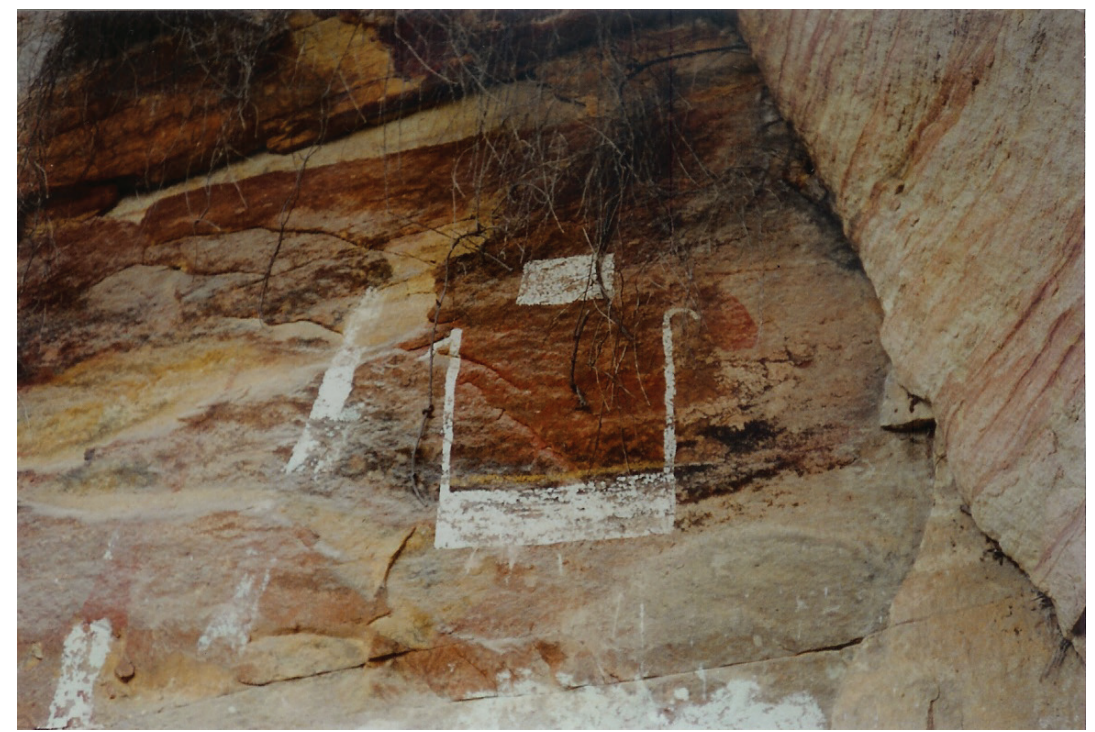

Figura 15. Pictografía de unku en el sitio arqueológico inca Chanque (cortesía de Arturo Ruiz)

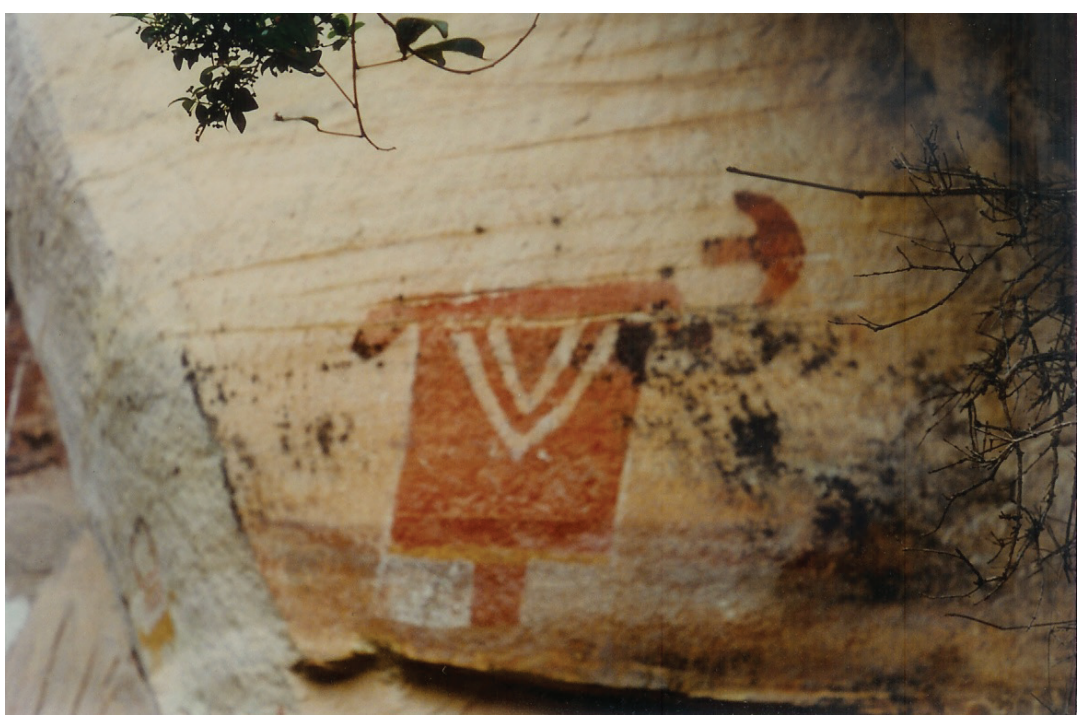

Figura 16. Pictografía de unku y tumi en el sitio arqueológico inca Chanque (cortesía de Arturo Ruiz) 


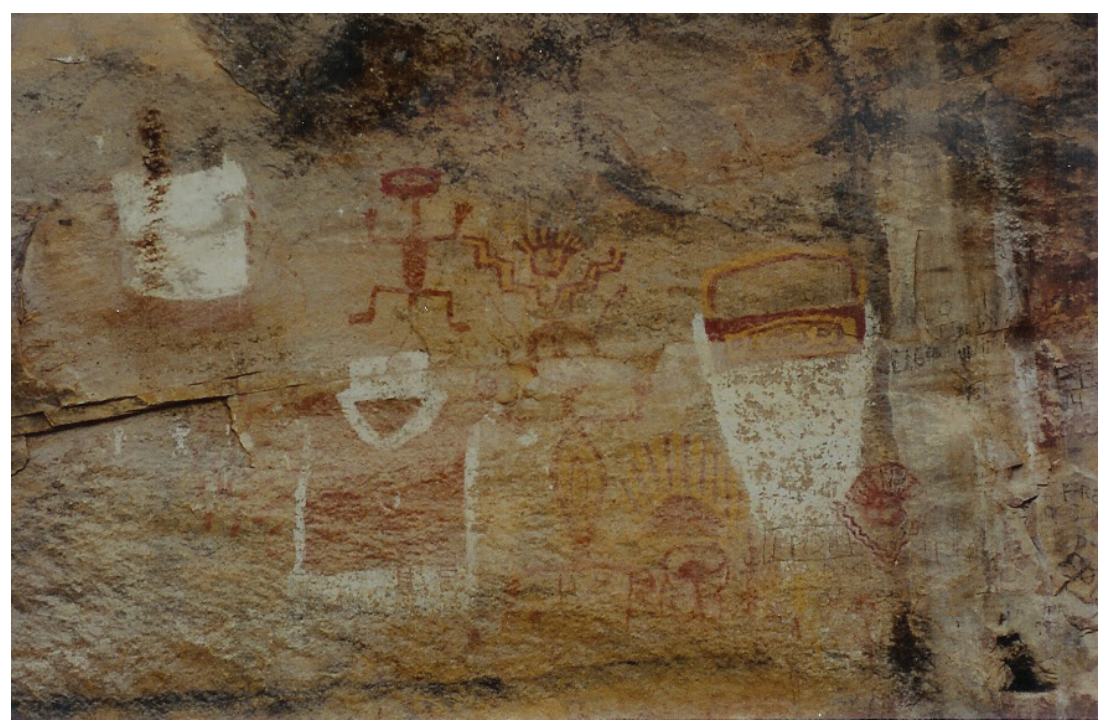

Figura 17. Pictografía de unkus y personajes estilizados en el sitio arqueológico inca Chanque (cortesía de Arturo Ruiz)

Comparando las características y componentes arqueológicos de estos sitios incas con los del sitio de Tupinachaca, se evidencian las semejanzas entre ellos. A partir de esto, podemos derivar algunas reflexiones en torno a la naturaleza y función que cumplió este lugar dentro de un contexto local y regional, así como a lo largo del tiempo.

\section{Tupinachaca: paisaje cultural y lugar de acontecimientos}

Todo paisaje cultural se encuentra en continua construcción y transformación, tanto por causas o agentes naturales como sociales. En este caso, es el conjunto de las diversas actividades humanas, específicamente los restos materiales de dichas acciones, lo que nos permite reconstruir paisajes concretos de una localidad en determinados períodos de tiempo. Dichas materialidades son producto de complejas relaciones entre diversos grupos de individuos y su entorno, las cuales se moldean por factores propios del contexto histórico y cultural. Por ello, nuestra reconstrucción del paisaje cultural de Tupe considera importante no solo el análisis y entendimiento de las dinámicas del sitio, sino también su integración a un contexto de desarrollo regional. Por las características observadas en las pictografías del cerro Tupinachaca, donde se desataca la presencia de elementos de estilo inca, de carácter militar, nos concentraremos en el período de expansión del imperio cusqueño. 


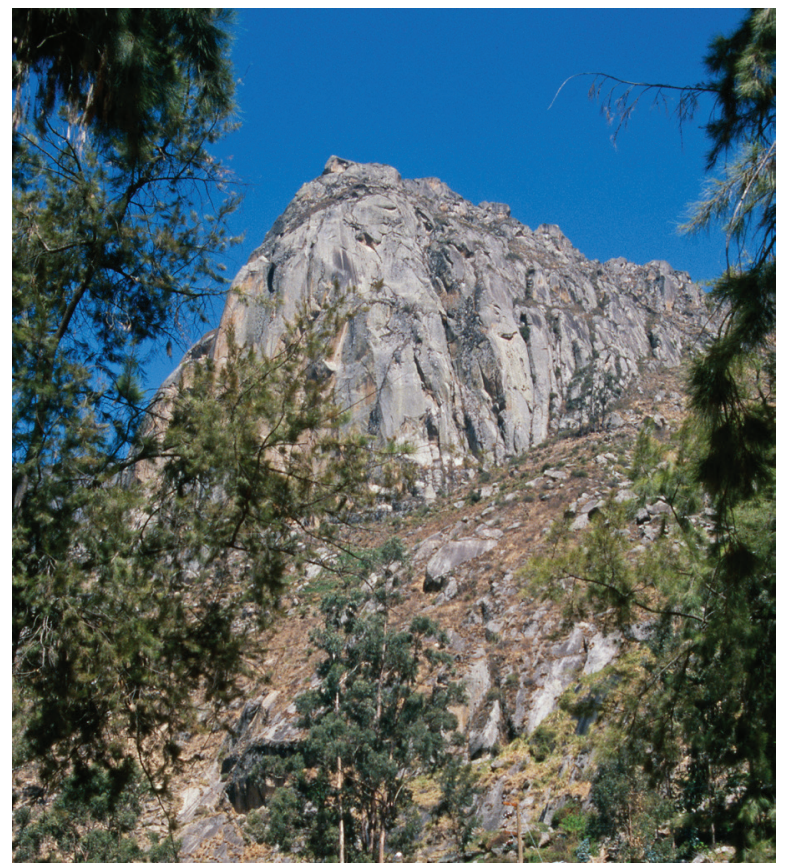

Figura 18. Cerro Tupinachaca

El tramo Tupe-Cotahuasi fue parte de la red de caminos transversales y de penetración del Qhapaq Ñan que permitió la movilización de los ejércitos (Ministerio de Cultura, 2013, p. 49), así como conectar diversos pueblos y centros administrativos y ceremoniales relacionados con el gobierno cusqueño y su capital, Cusco. De los varios centros de la costa y sierra central del Perú, quisiéramos destacar tres centros administrativos incas conectados entre sí a través de las vías principales del Qhapaq Ñan, los cuales tienen a la localidad de Tupinachaca y sus alrededores como una zona intermedia. Estos sitios son Hatun Xauxa en la actual provincia de Jauja, departamento de Junín; Vilcashuamán en la actual provincia de Vilcashuamán, departamento de Ayacucho; e Incahuasi en la actual provincia de Cañete, en el departamento de Lima. Tupinachaca se encuentra a 110 kilómetros de Hatun Xauxa, a 225 kilómetros de Vilcashuamán y a 50 kilómetros de Incahuasi; aunque las distancias no son similares, su ubicación fue un punto medio de tránsito entre estos tres centros administrativos (figura 19). 


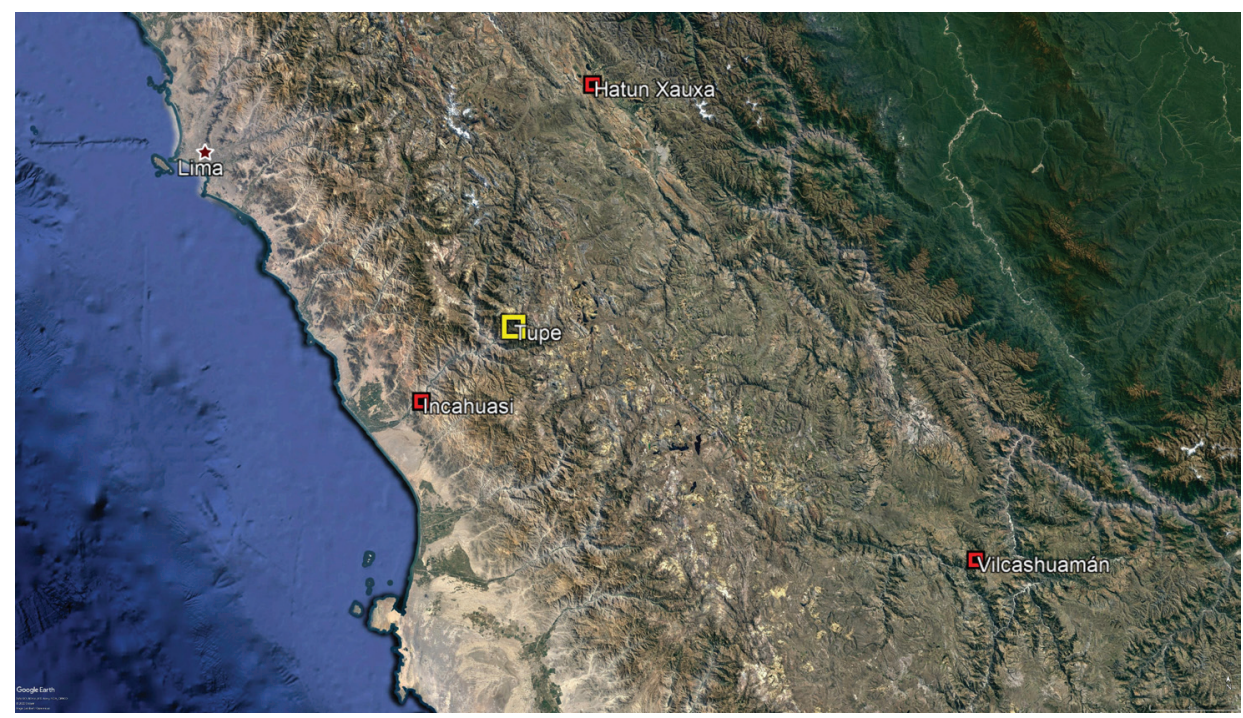

Figura 19. Ubicación de Tupe con respecto a los centros administrativos incas Hatun Xauxa, Incahuasi y Vilcashuamán. Las distancias en línea recta entre estos tres centros se encuentran marcadas en el mapa (sobre imagen satelital de Google Earth).

Cada uno de estos tres lugares pertenecía o se vinculaba directamente con una etnia diferente, teniendo como único denominador común su filiación política con el Tahuantinsuyo. Esto quedó expresado mediante las construcciones de corte imperial, especialmente representadas con elementos arquitectónicos como el ushnu (Pino, 2011).

Asimismo, cada uno de estos sitios albergaba depósitos o graneros entre sus construcciones. Recientemente, las excavaciones en el sitio de Incahuasi han confirmado estas funciones de abastecimiento para las tropas incas en su paso por la región. Si bien los escritos mencionan el almacenamiento de frutos y pescado seco salado, el registro arqueológico incluye principalmente restos de ají, frejol y maíz (Chu, 2018, p. 42).

Para el caso de Hatun Xauxa, investigaciones arqueológicas realizadas por el Proyecto Qhapaq Ñan del Ministerio de Cultura (Perales, 2016) brindan nuevos datos sobre su cronología, extensión y organización. Desde este centro administrativo se organizó a la población del valle del Mantaro y zonas aledañas, y también se administró la producción que se generaba para el imperio, para lo cual se construyeron más de mil colcas en el sitio (Ministerio de Cultura, 2019). Perales (2016) señala que ahí se produjeron también metales y cerámica. Los documentos coloniales describen la importancia del pastoreo de camélidos en Hatun Xauxa. 
De otro lado, se tiene información de que en el sitio de Vilcashuamán se almacenaban provisiones de guerra y alimentos como maíz, con los cuales se aprovisionaba al ejército con vestimenta, armas y comida cuando pasaba por allí (Santillana, 2012).

Cada uno de estos sitios estuvo emplazado muy cerca de grandes picos o montañas, apus locales, o estuvo relacionado con una conocida huaca local, mencionada en los documentos coloniales. Cerca de Hatun Xauxa se encuentra el Huaytapallana (a $5557 \mathrm{~m}$ s. n. m.); la montaña Moqo Alto y la laguna de Choclococha (a 4521 m s. n. m.) están en las inmediaciones de Vilcashuamán, mientras que, en el caso de la población costeña de Incahuasi, se conoce la adoración al mar (Mamacocha) y a la huaca El Huarco.

En Tupe, el apu Tupinachaca tuvo gran importancia local para la gente yauyo. Formaba una trinidad con otras dos huacas regionales, Pariacaca y Huallallo Carhuincho. Es interesante resaltar que, en tiempos de la Colonia, los españoles construyeron en Tupe una iglesia dedicada al santo patrono de la población, San Bartolomé apóstol (figura 20). Según algunos cronistas, la personalidad de este santo, junto a la de los apóstoles Tomás y Santiago y el propio Jesucristo, estuvieron asociadas en tiempos de la conquista y la Colonia temprana con la figura divina de Illapa, dios del trueno o rayo, una de las deidades supremas andinas, especialmente de la región altiplánica o aimara, donde se le conoce también como Tunupa Wiracocha (Polia, 1999, p. 85). Gregorio García (Valcárcel, 1985, p. 107) y el jesuita anónimo autor de la Relación de las costumbres antiguas de los naturales del Perú (1992, p. 58) detallan esta supuesta relación entre el apóstol Bartolomé y Tunupa. Esta simbiosis se debe aparentemente a similitudes de cierta imagen del dios Wiracocha que se encontraba en el Templo del Sol con la caracterización hispana del apóstol y sus conocidos viajes de evangelización a tierras lejanas como Persia, India y Armenia, lugar de su martirio y muerte ${ }^{2}$.

2 Se suma a estas imágenes la segunda más reverenciada por los tupinos: la Virgen de la Candelaria, advocación de la Virgen María que tiene su origen y mayor devoción en el departamento de Puno, territorio de población mayoritariamente aimara. Ello refuerza las teorías de los nexos culturales entre el pueblo de Tupe, su origen yauyo y la cultura aimara, camuflada en un sincretismo religioso muy discreto. 


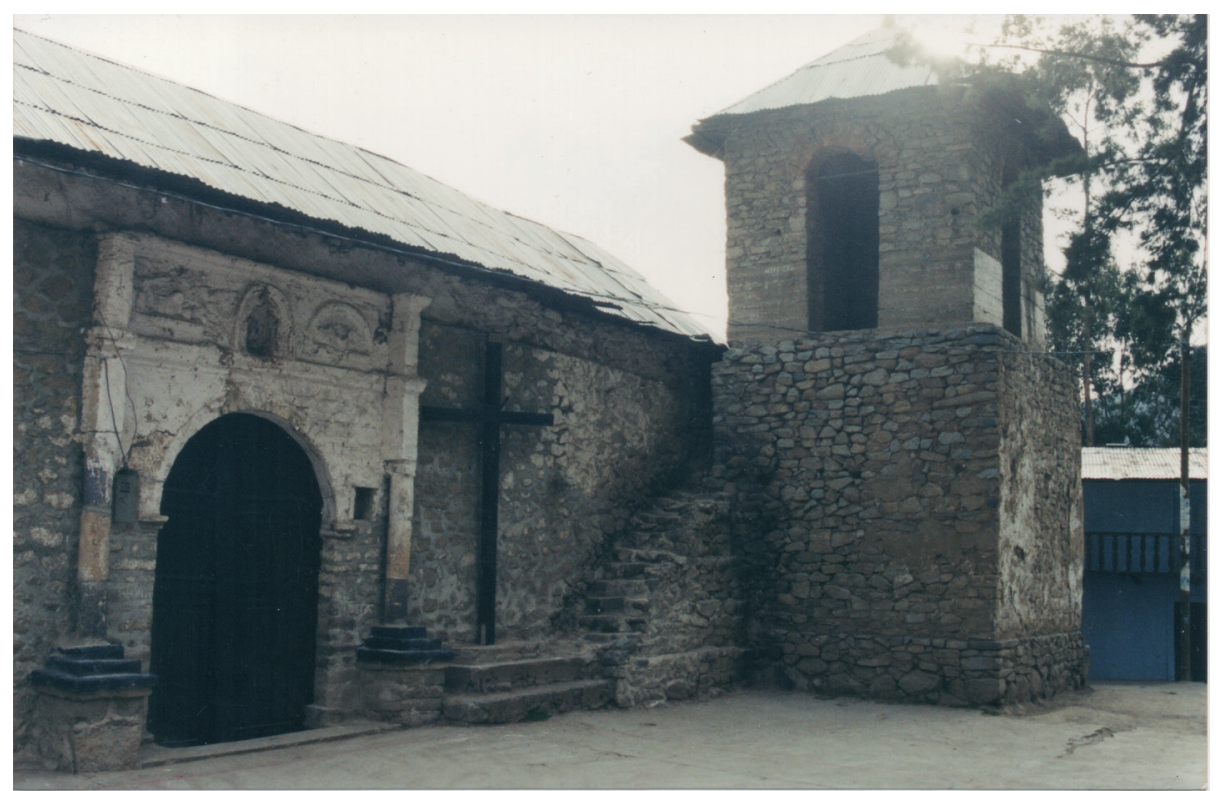

Figura 20. Iglesia colonial San Bartolomé

La ubicación intermedia del Tupinachaca podría haber tenido relevancia no solo para las huestes militares incas que se movilizaban entre la sierra y la costa, sino también para comerciantes, especialmente pastores de camélidos de las zonas altoandinas adyacentes de la región de Yauyos, y para peregrinos que transitaban hacia los diversos centros de peregrinación afiliados al imperio, como el santuario principal de la costa: Pachacamac.

Por un lado, huacas como Pariacaca y Huallallo parecen tener orígenes bastante remotos y sus cultos preceden en varios siglos al rendido al Sol o a Wiracocha, por lo que gozaban de un prestigio acumulado previamente. Lamentablemente, no contamos con una descripción precisa de la forma o las formas como se materializaban en el inconsciente de la gente estas huacas, de las que tenemos una descripción sucinta a través de algunos documentos coloniales tales como el manuscrito quechua de Huarochirí (Taylor, 1987). Por otro lado, las evidencias arqueológicas de actividades ceremoniales en Tupinachaca han demostrado su importancia local desde por lo menos el período Formativo.

Dentro del ámbito local, es muy probable que los pobladores de Tupinachaca hayan sido parte de la gran masa campesina de agricultores y pastores de la zona. El sitio de Campana-Torre o Cambanduri (a cuatro horas al este de Tupe, frente al actual poblado de Aiza) parece haber sido un asentamiento residencial de élite. En sus inmediaciones, se 
hallan estructuras arquitectónicas más sofisticadas que las observadas en Tupinachaca, entre las cuales hay chullpas o recintos funerarios. La presencia de estos mausoleos en las zonas de las cabeceras de los valles costeños fue para Villar Córdova (1935) una señal de la expansión de los yauyos. Estas chullpas eran estructuras funerarias de mayor rango y dimensiones que las mastabas o cistas, además de ser un elemento típico de las etnias aimaras desde la sierra limeña hasta el Altiplano peruano-boliviano.

La posición estratégica de Campana-Torre en una elevación menor que Tupinachaca, pero más escarpada y protegida, habría permitido visualizar desde allí gran parte del valle alto y medio de Cañete, lo cual incluye la observación de cientos de andenes agrícolas prehispánicos que continúan en uso en la actualidad. Sería, pues, un lugar idóneo para el control del territorio por parte de la élite dirigente. Cabe mencionar que el pueblo de Aiza es el anexo más importante de Tupe y donde también se conserva el uso cotidiano de vestimentas tradicionales y la lengua jaqaru.

Por su lado, Tupinachaca habría cumplido un rol ceremonial como espacio sagrado en donde los yauyos se identificarían con su lugar de origen, sus dioses y sus propios ancestros. Este cerro sería, pues, el apu, vivienda de vivos y muertos, guardián de las cosechas y el ganado, así como, probablemente, observatorio y oráculo del clima venidero. Recordemos que un apu, en el caso de cerros o rocas, está relacionado con el concepto de huaca (objeto o lugar sagrado) y con los héroes culturales, los lugares de origen o pacarinas y el lugar de donde brotan las aguas (Polia, 1999, pp. 182-183). Esta idea encuentra refuerzo en la traducción que el señor Isidoro Iturrizaga dio a la palabra Tupinachaca en 1941: "abuelo defensor" (Matos, 1956, p. 6).

Todas estas características nos permiten reconocer en un lugar como Tupinachaca un tinkuy, un espacio de encuentro entre diversas fuerzas o entidades, sean humanas, ancestrales o divinas, tanto locales como foráneas. Esto último cobra mayor vigencia cuando pensamos en Tupinachaca como un nodo de conexión con otros centros regionales vinculados al Tahuantinsuyo, lo cual nos permite reconocer también a este sitio como un nodo de encuentros administrativo-comerciales y políticos.

La presencia de elementos iconográficos incas, específicamente el uso de la camiseta o unku y el gorro o chuko, hace de los personajes de los paneles del Tupinachaca posibles representaciones de autoridades cusqueñas. Si esto fuese así, el Tupinachaca pudo funcionar también como un lugar de encuentro con el Otro, representado en la figura del poderoso gobernante foráneo, reconocible por todo aquel que pase frente a la ladera del gran apu local. Queda aún por determinar si este diseño en particular fue pintado por la propia autoridad cusqueña o fue realizado por los grupos locales. Poder esclarecer esto nos permitirá identificar si esta pictografía (y su articulación con los otros diseños) fue resultado de un acto de imposición estatal inca, o bien una manifestación local de sumisión frente al poder foráneo. 


\section{REFLEXIONES FINALES}

El Tupinachaca fue y es el gran apu protector de los tupinos. Su importancia en el pasado se acentúa con la presencia de las pictografías descritas en este artículo. Tales pictografías nos indican la relevancia de los camélidos en la economía de la zona, pero también un aparente vínculo con ritos religiosos.

Además de esto, las pinturas expuestas en los farallones presentan dos estilos claramente definidos, uno superpuesto al otro, lo que en nuestra opinión es un manejo o control del apu por parte de un nuevo poder. Este poder, dadas las características de algunos personajes y sus vestimentas (chuko y unku), sería el del Tahuantinsuyo, aunque falta definir si se trata de un control mediante la coerción, el sometimiento o la alianza de los antiguos yauyos con el imperio cusqueño.

Tanto Tupe como el Tupinachaca tuvieron una función crucial en la estrategia de control del Tahuantinsuyo, puesto que su ubicación se encontraba en un nudo de la red de caminos que conforma el Qhapaq Ñan. Tupe era punto intermedio entre grandes centros administrativos y económicos de la zona media del Tahuantinsuyo (sector sur del Chinchaysuyo): Incahuasi, Hatun Xauxa y Vilcashuamán, sitios que contenían grandes lugares de depósitos o colcas, así como ushnus, imponente arquitectura que representaba el dominio y la presencia del Sapa Inca en la zona. ¿Son las pictografías de personajes con unkus y chukos una marca similar a la de los ushnus antes mencionados?

Cabe mencionar que la carga "ideológica" del Tupinachaca tendría una historia muy larga para el pueblo de los yauyos, dado que, más allá de las pictografías, encontramos en sus laderas evidencia de cistas funerarias, material lítico como morteros y manos de moler, así como un "altar lítico" que, por sus características, se asemeja a los del período Formativo. Toda esta información podría confirmarse mediante excavaciones y un buen trabajo etnohistórico y antropológico, como el hecho desde la década de 1950 por los lingüistas que estudiaron el jaqaru y, de cierta manera, ayudaron a conservarlo.

Estos trabajos deberían darse en un futuro no muy lejano, puesto que la construcción de carreteras y la necesidad de los jóvenes tupinos de migrar romperán lo que aún queda de aislamiento de esta comunidad, poniendo en peligro sus tradiciones, así como su patrimonio cultural.

\section{REFERENCIAS}

Chu, A. (2018). Instalaciones imperiales en el sitio inca de Incahuasi, valle medio de Cañete. Boletín Yungas, 2(6), 37-44.

Del Carpio, M., Mac Kay, M., y Santa Cruz, R. (2001). Poro Poro: agua y religión en el Formativo de la sierra norte peruana. Arqueológicas, 24, 95-116. 
Delgado de Thays, C. (1959). Religión y magia en Tupe (Yauyos) (tesis doctoral en la especialidad de Etnología). Universidad Nacional Mayor de San Marcos.

Falcón, V. (2015). Inkapintay: arte rupestre de resistencia inca a la conquista española del Tawantinsuyu. Revista Haucaypata, 4(10), 24-43.

Guamán Poma de Ayala, F. (1993). Nueva corónica y buen gobierno. Tomo I (edición y prólogo de F. Pease G. Y.). Ciudad de México: Fondo de Cultura Económica.

Hostnig, R. (2017). Personajes de rango y emblemas de poder en pinturas rupestres incaicas del Valle Sagrado, Cusco, Perú. Tracce On Line Rock Arte Bulletin.

Matos Mar, J. (1951). La ganadería en la comunidad de Tupe. Lima: Instituto de Etnología UNMSM, publicación 2 .

Matos Mar, J. (1956). Yauyos, Tupe y el idioma kauke. Separata de la Revista del Museo Nacional, Tomo XXV. Lima: Instituto de Etnología UNMSM, publicación 12.

Ministerio de Cultura. (2013). Guía de identificación y registro del Qhapaq Ñan. Recuperado de https://qhapaqnan.cultura.pe/sites/default/files/mi/archivo/rcq.pdf

Ministerio de Cultura. (2019). Historia y uso del camino entre Xauxa y Pachacamac. Investigaciones arqueológicas e históricas. Lima: Autor.

Murúa, M. de (1962). Historia general del Perú, origen y descendencia de los incas (edición de M. Ballesteros Gabrois). Madrid: Biblioteca Americana Vetus (vol. 1).

Murúa, M. de (1964). Historia general del Perú, origen y descendencia de los Incas (edición de M. Ballesteros Gabrois). Madrid: Biblioteca Americana Vetus (vol. 2).

Pino, J. L. (2011). Yllapa usno: rituales de libación, culto a ancestros y la idea del ushnu en los Andes según los documentos coloniales de los siglos XVI-XVII. Arqueología y Sociedad, 21, 77-118.

Perales, M. (2016). Investigaciones arqueológicas en el sitio inca de Hatun Xauxa: nuevos datos sobre su cronología, extensión y organización. Cuadernos del Qhapaq Ñan, 4(4), 120-164.

Polia, M. (1999). La cosmovisión religiosa andina en los documentos inéditos del Archivo Romano de la Compañía de Jesús (1581-1752). Lima: Pontificia Universidad Católica del Perú, Fondo Editorial.

Relación de las costumbres antiguas de los naturales del Perú. (1992). En H. Urbano y A. Sánchez (Eds.), Antigüedades del Perú (pp. 43-122). Madrid: Crónicas de América, 70.

Rostworowski, M. (2002). El avance de los Yauyos hacia la costa en tiempos míticos. Pachacamac. Obras completas II (pp. 205-214). Lima: Instituto de Estudios Peruanos. 
Ruiz, A. (2007). Chanque: un santuario de arte rupestre en la región de Amazonas. En R. Hostnig, M. Strecker y J. Guffroy (Eds.), Actas del Primer Simposio Nacional de Arte de Rupestre (Cusco, noviembre del 2004) (pp. 97-111). Lima: Instituto Francés de Estudios Andinos.

Santillana, J. I. (2012). Paisaje sagrado e ideología inca. Vilcas Huaman. Lima: Institute of Andean Research; Pontificia Universidad Católica del Perú, Fondo Editorial.

Taylor, G. (Ed.). (1987). Ritos y tradiciones de Huarochirí. Manuscrito quechua de comienzos del siglo XVII. Lima: Instituto de Estudios Peruanos; Instituto Francés de Estudios Andinos.

Tello, J. C. (1929) Antiguo Perú. Primera época. Lima: Comisión Organizadora del Segundo Congreso Sudamericano de Turismo.

Torero, A. (2000). El marco histórico-geográfico en la interacción quechua-aru. Escritura y Pensamiento, 3(5), 9-58.

Torero, A. (2002). Idiomas de los Andes. Lingüística e historia. Lima: Instituto Francés de Estudios Andinos; Editorial Horizonte.

Valcárcel, L. E. (1985). Historia del Perú antiguo a través de la fuente escrita (vol. 6). Lima: Juan Mejía Baca, editor.

Vetter, L., y Mac Kay, M. (2008). Tupe: un pueblo detenido en el tiempo. Arqueología y Sociedad, 19, 265-292.

Villar Córdova, P. (1935). Las culturas prehispánicas del departamento de Lima. Homenaje al IV Centenario de la fundación de Lima o antigua Ciudad de los Reyes. Municipalidad de Lima. 